\title{
Protocol for extraction of genomic DNA from swine solid tissues
}

\author{
Fernando Henrique Biase, Maurício Machaim Franco, Luiz Ricardo Goulart and Robson Carlos Antunes \\ Universidade Federal de Uberlândia, Instituto de Genética e Bioquímica, Uberlândia, MG, Brazil
}

\begin{abstract}
Molecular diagnostics are performed by using DNA from different body tissues. However, it is necessary to obtain genomic DNA of good quality. Due to the impossibility of collecting blood from slaughtered animals, DNA extraction from solid tissues is necessary. The objective of this study was to describe a protocol of DNA extraction from swine skin, adipose, brain, liver, kidney and muscle tissues. We obtained high molecular weight DNA of good quality, shown by agarose gel and amplification of two DNA fragments, 605bp and $891 \mathrm{pb}$, by PCR. Spectrophotometric analysis of DNA concentration showed variation among the DNA from different tissues, with the liver and adipose tissues presenting the greatest and the smallest concentration, respectively. The described protocol has proven to be advantageous due to its simplicity, quickness, affordable reagents and absence of phenol, resulting in a high molecular weight DNA of good quality from several tissues.
\end{abstract}

Key words: DNA extraction, swine tissues.

Received: July 31, 2000; accepted: August 1, 2002.

\section{Introduction}

Professionals that control swine meat and carcass quality work basically with slaughtered animals, and it is not possible to collect blood for DNA extraction when genetic exams are needed. For this reason, DNA must be extracted from solid tissues.

Many genomic DNA extraction protocols have been described for prokaryotes and eukaryotes, from cell sample to specific tissues (Sambrook et al., 1989). However, there are not many studies using DNA from swine solid tissues.

Like reagents, good quality DNA is essential to achieve good results in experiments (Hoy, 1994), especially in the Polymerase Chain Reaction (PCR), in which excess of cell debris and proteins may inhibit the amplification process (Saiki, 1990).

Due to the importance of having good quality DNA extracted from solid tissues, this paper describes a fast and simple protocol for genomic DNA extraction from swine skin, adipose, brain, liver, kidney and muscle tissues.

Send correspondence to Fernando Henrique Biase. Universidade Federal de Uberlândia, Instituto de Genética e Bioquímica, Laboratório de Genética Molecular, Campus Umuarama, Bloco 2E sala 24, 38400-902 Uberlândia, MG, Brazil. E-mail: fernandobiase@ hotmail.com.

\section{Material and Methods}

Three samples from skin, adipose, brain, liver, kidney and muscle tissues were stored at $-20{ }^{\circ} \mathrm{C}$ after slaughter, from which DNA was extracted.

A sample consisted of a $200 \mathrm{mg}$ biopsy. Specimens were ground separately with mortar and pestle in liquid nitrogen. The frozen powder was transferred to a $2 \mathrm{~mL}$ eppendorf tube and $800 \mu \mathrm{L}$ of extraction solution $(50 \mathrm{mM}$ Tris-HCL, pH8.0; $25 \mathrm{mM}$ EDTA and $400 \mathrm{mM} \mathrm{NaCl}$ ), $100 \mu \mathrm{L} 10 \%$ SDS, and $20 \mu \mathrm{L}$ Proteinase K $(10 \mu \mathrm{g} / \mu \mathrm{L})$ were added. The extract was homogenized and incubated at $65^{\circ} \mathrm{C}$ for $3 \mathrm{~h}$. After incubation, proteins and cellular debris were precipitated by adding a $300 \mu \mathrm{L} 6 \mathrm{M} \mathrm{NaCl}$, kept at $4{ }^{\circ} \mathrm{C}$ for $15 \mathrm{~min}$. Centrifugation was done at $25,000 \mathrm{~g}$ for $20 \mathrm{~min} .500 \mu \mathrm{L}$ of the supernatant were transferred to a new eppendorf, with $500 \mu \mathrm{L} 8 \mathrm{M}$ guanidine hydrochloride (pH 8.0), and 0.49 $\mathrm{M}$ ammonium acetate solution, and kept in mild agitation for $90 \mathrm{~min}$. Nucleic acids were precipitated by adding $800 \mu \mathrm{L}$ of cold $100 \%$ isopropyl alcohol, followed by centrifugation at $8,000 \mathrm{~g}$ for $5 \mathrm{~min}$. Pellets were washed with $400 \mu \mathrm{L}$ of $70 \%$ isopropyl alcohol. After drying, pellets were resuspended in $150 \mu \mathrm{L}$ TE buffer $(10 \mathrm{mM}$ Tris-HCl, pH 8.0; $1 \mathrm{mM}$ EDTA and $50 \mu \mathrm{g} / \mu \mathrm{L}$ RNAse). DNA samples were stored at $4{ }^{\circ} \mathrm{C}$.

DNA quality and concentrations were evaluated by spectrophotometer and by ethidium bromide-stained 
agarose gel under Ultraviolet light. Photographs were documented through a Videodocumantetion system, the VDS ImageMaster (Pharmacia Biotech).

Fragments chosen to probe DNA integrity are in different regions of the porcine Growth Hormone gene. A $605 \mathrm{pb}$ fragment was amplified under the following conditions: $100 \mathrm{ng}$ of genomic DNA, 1U Taq DNA Polymerase, $0.5 \mu \mathrm{M}$ Primer, $400 \mu \mathrm{M}$ dNTP, Taq buffer $1 \mathrm{X}$ and $3 \mathrm{mM}$ $\mathrm{MgCl}_{2}$. Another fragment, $891 \mathrm{bp}$, was amplified in the following conditions: $100 \mathrm{ng}$ genomic DNA, 1U Taq DNA Polymerase, $0.2 \mu \mathrm{M}$ Primer, $400 \mu \mathrm{M}$ dNTP, Taq buffer $1 \mathrm{X}$ and $1.5 \mathrm{mM} \mathrm{MgCl}_{2}$. Both in a $20 \mu \mathrm{L}$ final volume.

\section{Results and Discussion}

The protocol was efficient in extracting genomic DNA from all solid tissues. Analysis of whole genomic DNA in agarose gel (Figure 1) and amplified fragments (605 and $891 \mathrm{bp}$ ) by PCR (Figures $2 \mathrm{a}$ and b) demonstrated that the extracted DNA had high molecular weight, one of the most important aspects for successful amplifications of larger fragments (Borges, 1997).

\section{$\begin{array}{llllllllllll}\mathbf{S} & \mathbf{S} & \mathbf{K} & \mathbf{K} & \mathbf{B} & \mathbf{B} & \mathbf{L} & \mathbf{L} & \mathbf{M} & \mathbf{M} & \mathbf{A} & \mathbf{A}\end{array}$}

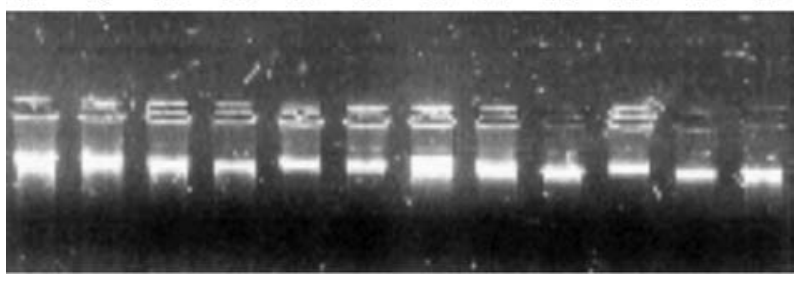

Figure 1 - Genomic DNA sample submitted to electrophoresis in $0.8 \%$ agarose gel. (S) Skin, (K) Kidney, (B) Brain, (L) Liver, (M) Muscle and (A) Adipose tissues.
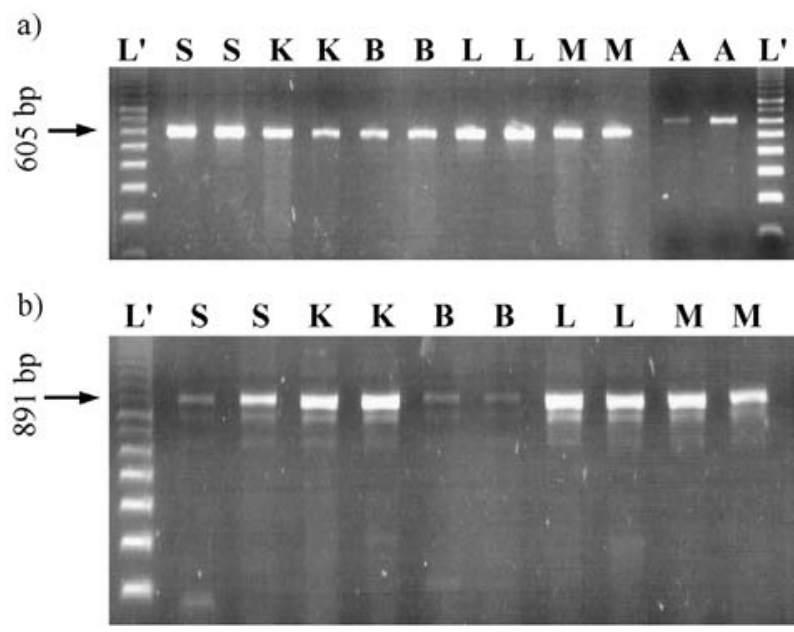

Figure 2 - a: 605bp fragment amplified by PCR visualized in $1.5 \%$ agarose gel under UV light. (L') 100bp DNA Ladder, (S) Skin, (K) Kidney, (B) Brain, (L) Liver, (M) Muscle and (A) Adipose tissues. b: 891bp fragment amplified by PCR visualized in $1.5 \%$ agarose gel under UV light. (L') 100pb DNA Ladder, (S) Skin, (K) Kidney, (B) Brain, (L) Liver, (M) Muscle and (A) Adipose tissues.
Table I - DNA concentration and OD ratio (A260/A280) of DNA extracted from different tissues.

\begin{tabular}{lcc}
\hline Tissues & DNA concentration $(\overline{\mathrm{x}}) \eta \mathrm{g} / \mu \mathrm{L}$ & OD260/OD280 $(\overline{\mathrm{x}})$ \\
\hline Liver & 1950 & 2.05 \\
Kidney & 840 & 2.23 \\
Brain & 486.6 & 1.93 \\
Muscle & 483.3 & 1.80 \\
Skin & 160 & 2.24 \\
Adipose & 33.3 & $*$ \\
\hline
\end{tabular}

*Spectrophotometric readings did not detect proteins.

Spectrophotometer measurements indicated differences in DNA concentration and purity, according to the tissue origin (Table I). Higher concentrations were obtained from the liver, kidney and brain tissues, similar to those obtained by Atmadja et al. (1995) for human tissues. The OD260/OD280 ratio values satisfied those suggested by Sambrook et al. (1989), $\geq 1.8$, which were higher than those obtained by Akane et al. (1993) and Atmadja et al. (1995).

The variability in DNA quality and purity can be explained by tissue specific structural complexity. Liver, kidney and brain tissues are composed of delicate membrane cells with few fibrous cells. On the other hand, the skin consists of stratified tissue with keratin and other fibrous cells. The muscle tissue is constituted by many proteins within the cell. Adipose tissue consists mainly of lipids, which increase cell volume and decrease cell number. In addition, lipid is water insoluble, which hinders extraction, lysing a smaller number of nuclei (Junqueira and Carneiro, 1995).

This protocol proved to be advantageous because of its simplicity, quickness and affordable reagents, besides the high molecular weight DNA and purity achieved in a variety of tissues. Furthermore, there is no phenol in DNA purification, known as a strong PCR inhibitor (Saiki, 1990).

\section{Acknowledgments}

The authors gratefully acknowledge Granja Rezende S.A. for donations of the biological material, and also would like to thank Juliana Alves São Julião, Cícero Donizete Pereira and Guilherme Rocha Lino de Souza for their suggestions. The CAPES foundation has partially financed this research through the Special Training Program (PET) scholarship awarded to Fernando H. Biase.

\section{References}

Akane A, Shiono H, Matsubara K, Nakamura H, Hasegawa M and Kagawa M (1993) Purification of Forensic Specimens for the Polimerase Chain Reaction (PCR) Analysis. J of Forensic Sci 38: 691-701.

Atmadja DS, Tatsuno Y, Ueno Y and Nishimura A (1995) The effect of extraction methods, the kind of organs samples and 
the examination delay on the yields and typing. K. J Med Sci 41:197-211.

Borges M (1997) Marcadores moleculares e seus efeitos sobre características quantitativas de bovinos de corte. MSc Dissertation, Universidade Federal de Uberlândia, Uberlândia.

Hoy MA (1994) DNA Amplification by the Polymerase Chain Reaction: Molecular Biology Made Accessible. In: Hoy MA. Insect Molecular Genetics: An Introduction Principles and Applications, Academic Press, San Diego, pp 203-244.
Junqueira LC and Carneiro J (1995) Histologia Básica. Guanabara Koogan S.A, Rio de Janeiro, 512 pp.

Saiki RK (1990) Amplification of genomic DNA. In: Iinnis MA, Gelfand DH, Sninski JJ and White TJ. PCR Protocols: A Guide to Methods and Applications. Academic Press. San Diego, pp 13-20.

Sambrook J, Fritschi EF and Maniatis T (1989) Molecular cloning: a laboratory manual, Cold Spring Harbor Laboratory Press, New York. 